\title{
Pengaruh Model Project Based Learning Berbantuan Penilaian Portofolio Terhadap Literasi Sains
}

\author{
L. D. Anggreni ${ }^{1}$, I N. Jampel ${ }^{2}$, K. S Diputra ${ }^{3}$ \\ ${ }^{123}$ Prodi Pendidikan Guru Sekolah Dasar, FIP \\ Universitas Pendidikan Ganesha, Singaraja, Indonesia \\ e-mail: anggrenidewi30@gmail.com¹, jampel@undiksha.ac.id ${ }^{2}$, \\ komangsujendra.diputra@undiksha.ac.id ${ }^{3}$.
}

\begin{abstract}
Abstrak
Penelitin ini bertujuan untuk mengetahui pengaruh model Project Based Learning berbantuan penilaian portofolio terhadap literasi Sains siswa kelas V SD Gugus IV Kecamatan Sawan, Kabupaten Buleleng. Populasi penelitian ini adalah siswa kelas V di SD Gugus IV Kecamatan Sawan yang berjumlah 164 orang. Sampel penelitian ini adalah kelas V SDN 1 Bungkulan yang berjumlah 21 orang dan kelas V SDN 4 Bungkulan yang berjumlah 21 orang. Data dikumpulkan dengan instrumen tes literasi sains. Data yang dikumpulkan dianalisis menggunakan analisis statistik deskriptif dan statistik inferensial (uji-t). Berdasarkan hasil analisis, diperoleh $t_{\text {hitung }}=12,27>t_{\text {tabel }}=2,021$. Hal ini berarti diinterpretasikan bahwa terdapat perbedaan yang signifikan literasi sains antara kelompok siswa yang dibelajarkan dengan model Project Based Learning berbantuan penilaian portofolio dan kelompok siswa yang tidak dibelajarkan dengan model Project Based Learning berbantuan penilaian portofolio. Dari rata-rata hitung, diketahui rata-rata hitung kelompok eksperimen adalah 41, 52 dan rata-rata hitung kelompok kontrol adalah 29, 62. Hal ini berarti rata-rata hitung eksperimen lebih besar rata-rata hitung kelompok kontrol, sehingga dapat disimpulkan penerapan model Project Based Learning berbantuan penilaian portofolio berpengaruh terhadap literasi Sains siswa kelas V SD Gugus IV Kecamatan Sawan.
\end{abstract}

Kata Kunci: literasi sains, portofolio, project based learning

\begin{abstract}
The aimed of this research was to determine the effect of the Project Based Learning model assisted with portfolio on fifth grade students' science literacy of elementary school of cluster IV in Sawan District, Buleleng Regency. The population of this research was fifth grade elementary students of cluster IV, Sawan Sub district which was consisted of 164 students. The sample of this research was fifth grade students of SD 1 Bungkulan which numbered of 21 students and fifth grade students of SD Negeri 4 Bungkulan which numbered of 21 students. The data was collected by using science literacy test instrument. The data collection was analyzed by using descriptive statistics analysis and inferential statistics (t-test). Based on the results of the analysis, it obtained $t$-count $=12.27>t$-table $=2,021$. It meant that there were significant differences in science literacy between groups of students who were taught with Project Based Learning models assisted by portfolio and student group assessments that were not taught by the Project model Based Learning assisted by portfolio evaluation. From the calculation, it was known that the average score of the experimental group was 41, 52 and the average score of the control group was 29,62. This meant that the average score of experiment > than the average score of the control group, so it could be concluded that the application of the model Project Based Learning assisted by an influential portfolio assessment had an effect of the science literacy on fifth grade elementary students of Cluster IV in Sawan Subdistrict.
\end{abstract}

Keywords: science literacy, portofolio, project based learning.

\footnotetext{
*Corresponding author.

Received 20 January 2020, Accepted 20 March 2020; Available online 5 Appril 2020 (C) 2020 MI All Rights Reserved
} 


\section{Pendahuluan}

Persaingan yang ketat pada era modern ini menuntut manusia untuk aktif dan kreatif dalam mengembangkan potensi diri. Salah satu cara untuk memenangkan persaingan di era tersebut adalah dengan memiliki sumber daya manusia profesional yang berkualitas tinggi. Peningkatan kualitas sumber daya manusia dan profesionalisme dalam berbagai bidang kehidupan masyarakat harus menjadi prioritas utama pembangunan suatu bangsa dan negara. Potensi diri menjadi manusia yang berkualitas dan mampu bersaing dapat diwujudkan dengan melewati proses pendidikan.

Melalui pendidikan setiap manusia disediakan berbagai kesempatan belajar untuk meningkatkan pengetahun, keterampilan, dan sikap untuk dapat menyesuaikan diri dengan kehidupan bermasyarakat. Sebagaimana tercantum dalam rumusan tentang pendidikan yang termuat dalam Undang-undang sistem Pendidikan Nasional yaitu UU No. 20 Tahun 2003, bahwa "Pendidikan Nasional bertujuan untuk berkembangnya potensi peserta didik agar menjadi manusia yang beriman dan bertakwa kepada Tuhan Yang Maha Esa, beakhlak mulia, sehat, berilmu, cakap, kreatif, mandiri, dan menjadi warga negara yang demokrats, serta bertanggung jawab".

Berdasarkan tujuan pendidikan nasional, maka sangat diharapkan peningkatan sumber daya manusia (SDM) yang berkualitas tinggi.Hal ini dikarenakan kualitas sumber daya manusia (SDM) merupakan kekuatan yang utama dalam menggerakkan roda pembangunan. Berkaitan dengan upaya peningkatan kualitas SDM tersebut, maka peserta didik diharapkan mampu memecahkan masalah belajar saat usia sekolah dasar. Guru diharapkan mampu menjadi fasilitator yang baik dalam memecahkan masalah tersebut agar tujuan pendidikan nasional dapat terwujud sesuai harapan bangsa.

Memasuki abad ke-21, penguasaan Sains dan teknologi menjadi kunci penting keberhasilan suatu bangsa.Kemajuan zaman mengakibatkan meningkatnya daya saing bangsa pada saat masuk pada era MEA (Masyarakat Ekonomi Asean) yang mengakibatkan adanya produk-produk kerja ilmiah disertai dengan kemampuan literasi Sains yang dijadikan sebagai kewajiban untuk dipelajari pada abad ini (Astutik, 2019).Masyarakat modern membutuhkan literasi Sains untuk menyikapi berbagai isu atau masalah yang berhubungan dengan bidang Sains dan teknologi (Masruroh \& Zuhdan, 2018).Pendidikan Sains sebagai bagian dari pendidikan secara umumbertanggung jawab dan berperan penting dalam menghasilkan peserta didik yang memiliki kemampuan berpikir kritis, logis, kreatif, inovatif, dan berdaya saing global. Sehingga dalam hal ini, pada proses pembelajaran harus memungkinkan siswa untuk mengembangkan rasa ingin tahunya, mengajarkan keterampilan-keterampilan yang bermanfaat untuk kehidupan siswa di masa depan dan memungkinkan siswa untuk bekerja secara kolaboratif dalam memecahkan permasalahan (Yuliati, 2019). Jadi mata pelajaran untuk mengasah keterampilan abad 21 adalah Ilmu Pengetahuan Alam/Sains.

Sains menjadi mata pelajaran di tingkat Sekolah Dasar (SD), SMP, SMA, dan Universitas.Pada masa kemerdekaan, Sains dinamakan ilmu pasti, yang kemudian berubah menjadi IPA untuk tingkat SD (Al-Tabany, dkk, 2015: 132)."Sains adalah ilmu yang mempelajari segala sesuatu hal yang ada di alam dan sekitarnya”, adapun tujuan mempelajari Sains adalah penguasaan dan kepemilikan literasi Sains (peserta didik) yang membantu peserta didik memahami Sains dalam konten-proses-konteks yang lebih luas terutama dalam kehidupan sehari-hari (Fatmala, 2017). Kurikulum pada mata pelajaran IPA yang berkaitan dengan literasi Sains diantaranya pembelajaran IPA harus dapat menumbuhkan kepercayaan diri siswa, belajar tentang IPA harus disertai dengan pengembangan sikap dan keterampilan ilmiah, belajar IPA hendaknya membuat siswa dapat menggunakan pengetahuan yang dimilikinya untuk memahami kejadian-kejadian alam yang ada disekitar, belajar IPA harus dapat mengembangkan "keterampilan proses Sains" (Fitariya, 2018). Berdasarkan uraian mengenai pembelajaran IPA pada kurikulum IPA masa depan akan terfokus pada pengembangan sikap ilmiah, keterampilan ilmiah, kemampuan bernalar, kemampuan melakukan penyelidikan ilmiah, keterampilan proses Sains, dan kepercayaan diri, dan semua itu berorientasi pada literasi Sains. 
Literasi Sains berasal dari gabungan dua kata latin yaitu Literatus, artinya ditandai dengan huruf, melek huruf, atau pendidikan dan scientia, yang artinya memiliki pengetahuan. Literasi sains adalah kemampuan menggunakan pengetahuan Sains, mengidentifikasi pertanyaan, dan menarik kesimpulan berdasarkan bukti-bukti, dalam rangka memahami serta membuat keputusan berkenaan dengan alam dan perubahan yang dilakukan terhadap alam melalui aktivitas manusia (Fitariya, 2018).

Terdapat tiga kompetensi ilmiah yang diukur dalam literasi Sains diuraikan sebagai berikut. Pertama, mengidentifikasi isu-isu (masalah) ilmiah: mengenali masalah yang mungkin untuk penyelidikan ilmiah, mengidentifikasi kata kunci untuk mencari informasi ilmiah, mengenali fitur kunci dari penyelidikan ilmiah. Kedua, menjelaskan fenomena ilmiah: menerapkan ilmu pengetahuan dalam situasi tertentu, menggambarkan atau menafsirkan fenomena ilmiah dan memprediksi perubahan, mengidentifikasi deskripsi yang tepat, memberikan penjelasan dan prediksi. Ketiga, menggunakan bukti ilmiah: menafsirkan bukti ilmiah dan membuat kesimpulan dan mengkomunikasikan, mengidentifikasi asumsi, bukti dan alasan di balik kesimpulan, berkaca pada implikasi sosial dari ilmu pengetahuan dan perkembangan teknologi (Odja, 2014).

Literasi Sains (Scientific literacy) menjadi suatu keharusan dan merupakan kebutuhan bagi setiap siswa (Gherardini, 2016)."Literasi Sains merupakan tolak ukur keberhasilan dari pendidikan IPA di sekolah" (Aqil, 2017).Pendidikan Sains bertanggung jawab atas pencapaian literasi Sains anak bangsa, karena itu perlu adanya peningkatan kualitas pendidikan Sains.Sains sebagai bagian dari pendidikan pada umumnya berperan penting untuk menyiapkan peserta didik yang mampu berpikir kritis, kreatif, logis, dan berinisiatif dalam menanggapi isu di masyarakat yang diakibatkan oleh dampak perkembangan Sains dan teknologi (Gherardini, 2016).Proses Sains harus menekankan pada pemberian pengalaman langsung untuk mengembangkan kompetensi agar menjelajahi dan memahami alam sekitar secara ilmiah.

Penilaian literasi Sains merupakan komponen yang penting dalam belajar dan pembelajaran.Pandangan literasi Sains menggabungkan pemahaman Sains yang luas melebihi dari konsep mata pelajaran dan prosedur penyelidikan ilmiah.Maka dari itu, siswa harus bersungguh-sungguh dalam pembelajaran IPA karena sangat penting dalam mengenalkan lingkungan alam dan sekitar kita dengan tujuan untuk meningkatkan literasi Sains siswa SD.

Namun literasi Sains merupakan salah satu permasalahan pendidikan di Indonesia yang membutuhkan perhatian untuk segera teratasi. Rendahnya mutu hasil belajar Sains siswa menunjukkan bahwa proses belajar Sains di Indonesia kurang melatih literasi Sains siswa. Kecenderungan pembelajaran saat ini adalah peserta didik mempelajarinya sebagai produk, menghapal konsep, teori dan hukum. Kemampuan literasi di Indonesia masih rendah, hal ini dibuktikan dengan hasil evaluasi oleh lembaga Internasional Organization for Ecomomic Cooperation and Development (OECD) melalui PISA (Programme for International Student Assessment) tentang pengukuran prestasi IPA peserta didik. Kemampuan literasi Sains siswa di Indonesia selalu berada pada peringkat rendah.Pengukuran PISA terakhir yaitu tahun 2015 menunjukkan bahwa Indonesia berada pada urutan 62 dari 70 negara (OECD, 2016).Berdasarkan hasil survei tersebut skor siswa Indonesia pada kemampuan literasi Sains masih jauh di bawah skor standar Internasional yang ditetapkan oleh Lembaga OECD. Rendahnya skor perolehan siswa Indonesia mencerminkan rendahnya literasi Sains anak Indonesia.

Salah satu penelitian yang menyatakan bahwa masih lemahnya kegiatan pembelajaran yang sesuai hakikat Sains adalah penelitian menurut (Huryah, 2017) yang menyatakan bahwa rata-rata kemampuan Sains di Indonesia baru sampai pada kemampuan mengingat dan mengenali pengetahuan ilmiah berdasarkan fakta sederhana, tetapi belum mampu untuk mengkomunikasikan dan mengaitkan berbagai topik Sains, apalagi menerapkan konsepkonsep yang kompleks dan abstrak di dalam kehidupan sehari-hari.

Hasil observasi di SD Gugus IV Kecamatan Sawan, Kabupaten Buleleng, ketika dilakukan wawancara dan observasi dengan guru kelas V pada tanggal 7 Januari 2019 tentang permasalahan rendahnya literasi Sains di SD Gugus IV kecamatan Sawanadalah sebagai 
berikut: 1) Penguasaan literasi Sains siswa kategori rendah, hal ini dapat dibuktikan dari hasil wawancara guru kelas terkait pemahaman siswa terhadap tiga kompetensi utama literasi Sains menurut PISA yaitu: 1. Aspek mengidentifikasi isu-isu (masalah) ilmiah: siswa belum bisa mengenali sebuah objek yang digunakan sebagai masalah ilmiah dalam proses pembelajaran, ketika diberikan permasalahan, siswa hanya berusaha menjawab sebisa mungkin tanpa mengetahui kata kunci dari permasalahan yang telah diberikan itu. 2. Aspek menjelaskan fenomena ilmiah: siswa belum sepenuhnya dapat mengaplikasikan pengetahuan Sains yang diberikan saat pembelajaran ke dalam situasi atau kondisi yang diberikan, sehingga siswa tidak dapat menerapkan teori-teori Sains di sekolah untuk digunakan dalam kehidupan sehari-hari. Selain itu, siswa sulit memprediksi perubahan apa yang terjadi saat diberikan suatu permasalahan untuk dicari tahu kebenarannya. 3. Aspek menggunakan bukti ilmiah: siswa sulit memaknai hasil temuan ilmiah yang telah dipelajari, sehingga kemampun siswa masih kurang dalam menyimpulkan bukti dari permasalahan yang diberikan. Dengan kata lain, siswa tidak mampu berargumen menggambarkan dampak yang logis dari suatu temuan. 2) Pembelajaran didominasi oleh guru, terkadang didominasi oleh siswa yang berprestasi. Hal ini diinformasikan oleh wali kelas $\mathrm{V}$, bahwa saat proses pembelajaran berlangsung siswa berprestasilah yang lebih aktif, sedangkan siswa yang memiliki kemampuan kurang akan mengikuti pendapat siswa berprestasi atau bahkan hanya tidak merespon pertanyaan guru, 3) Kerjasama siswa kurang, karena guru terbiasa memberikan ceramah dan jarang menugaskan siswa untuk bekerja secara kolaboratif

Hasil observasi dalam proses pembelajaran umumnya: 1) Guru memulai dengan penyajian materi yang berkaitan dengan konsep yang akan dipelajari siswa, tanya jawab, pemberian contoh soal, kemudian dilanjutkan dengan pemberian tes. 2) Guru jarang melibatkan siswa untuk berkelompoksehingga siswa kurang memiliki rasa kerjasama. 3) Guru jarang melibatkan siswa dalam pelaksanaan investigasi atau kegiatan yang mengantarkan siswa untuk menemukan sendiri jawaban dari suatu fenomena. 4) Alat peraga dan media yang diciptakan guru sangat terbatas, sehingga buku merupakan sumber guru dalam proses pembelajaran IPA/Sains. 5) Belum menggunakan model-model bervariasi dan guru sulit menerapkan model Projet Based Learningberbantuan penilaian portofolio, sehingga pembelajaran sangat monoton dan tidak pernah berubah. Jika masalah tersebut tidak segera dituntaskan, maka akan berdampak pada rendahnya literasi Sains siswa di gugus tersebut.

Berdasarkan hal tersebut, guru sebagai pemegang peranan penting dalam proses pembelajaran diharapkan dapat mencari solusi dari permasalahan di atas dengan cara mendesain atau merancang kegiatan literasi Sains yang berorientasi pada keaktifan siswadengan cara memanfaatkan lingkungan sekitar sebagai media pembelajaran. Selain itu, guru juga dapat memanfaatkan kecanggihan teknologi sebagai media pembelajaran yang berguna untuk menunjang kegiatan pembelajaran. Guru harus mampu kreatif serta memanfaatkan apa yang ada dalam kegiatan proyek untuk mendukung proses pembelajaran. Selain media, guru diharapkan dapat menggunakan model-model pembelajaran yang sesuai dengan karakteristik siswa dan karakteristik materi ajarnya. Banyak kejadian guru terkecoh dan kurang tepat dalam pengaplikasian model pembelajaran yang menyebabkan rasa bosan pada siswa untuk belajar sehingga penguasaan Sains siswa tidak dapat dikembangkan. Maka dari itu, perlunya penggunaan metode, media, dan model pembelajaran yang tepat dan cocok diterapkan agar pembelajaran Sains lebih bermakna.

Pemilihan model pembelajaran yang menyenangkan untuk meningkatkan literasi Sains siswa sekolah dasar adalah model Project Based Learning. Model Project Based Learning sangat cocok dalam penerapan literasi Sains. Hal ini sesuai dengan penelitian Septarini menunjukkan bahwa penerapan model Project Based Learning dapat meningkatkan kemampuan pemahaman konsep sifat-sifat cahaya pada siswa kelas V SD N 1 Doplang (Wulandari, 2018). Maka dari itu dapat dikatakan bahwa model PjBL ini dapat meningkatkan kemampuan siswa tentang alam dan penerapannya dalam kehidupan sehari-hari serta mampu memecahkan masalah terkait Sains.

Model Project Based Learning adalah model pembelajaran yang memberikan kesempatan kepada guru untuk mengelola pembelajaran di kelas dengan melibatkan kerja 
proyek (Mulyadi, 2015). Kerja proyek memuat tugas-tugas yang kompleks berdasarkan permasalahan (problem) yang diberikan kepada siswa sebagai langkah awal dalam mengumpulkan dan mengintegrasikan pengetahuan baru berdasarkan pengalamannya dalam beraktivitas secara nyata, dan menuntut siswa untuk melakukan kegiatan merancang, menerapkan proses IPA, melatih sikap, melakukan kegiatan investigasi/penyelidikan, memecahkan masalah, membuat keputusan, memberikan kesempatan kepada siswa untuk bekerja mandiri maupun kelompok.

Pembelajaran berbasis proyek ini lebih memusatkan pada masalah kehidupan yang bermakna bagi siswa, peran guru menyajikan masalah, mengajukan pertanyaan dan memfasilitasi siswa dalam merancang sebuah proyek yang akan dilakukan. Dan ini akan menambah kreativitas siswa dalam merancang sebuah proyek yang kemudian mereka kerjakan dalam waktu yang sudah disepakati.

Langkah-langkah model Project Based Learning meliputi: (1) mengajukan pertanyaan mendasar, (2) mendesain perencanaan projek, (3) menyusun jadwal, (4) memonitoring peserta didik dan kemajuan projek, (5) menguji hasil, dan (6) mengevaluasi pengalaman (Redhana, 2019).

Dalam implementasiannya, model Project Based Learningdiintegrasikan dengan penilaian portofolio, karena penilaian portofolio merupakan suatu pendekatan penilaian yang komprehensif yang mencangkup ranah kognitif, afektif, dan psikomotor (Dharsana, 2014). Portofolio adalah semua benda yang berbentuk bukti fisik sebagai sesuatu yang menunjukkan hasil kinerja peserta didik. Dengan adanya penilaian portofolio kepada siswa, siswa dapat bertanggung jawab untuk menyimpannya dengan baik oleh mereka sendiri. Dengan sabar mencermati portofolio, siswa akan dapat mengetahui bagaimana peningkatan dan riwayat kinerja mereka sendiri, sehingga dapat memperhitungkan upaya yang harus mereka perbaiki dari waktu ke waktu. Akan lebih baik lagi apabila siswa melakukan instrospeksi dari waktu ke waktu ketika memperoleh nilai dari hasil kinerjanya (Arikunto, 2016).

Dengan diterapkannya model Project Based Learning berbantuan penilaian portofolio, siswa akan ditugaskan untuk mengidentifikasi permasalahan terlebih dahulu sebelum diberikan tugas sebuah proyek, sehingga siswa akan terbiasa mengidentifikasi isu-isu atau masalah ilmiah. Maka dari penerapan model pembelajaran tersebut, kemampuan siswa dalam mengidentifikasi isu-isu ilmiah, menjelaskan fenomena ilmiah, dan menggunakan bukti-bukti ilmiah yang terdapat pada kompetensi literasi Sains akan meningkat. Memperhatikan uraian masalah tersebut di atas, maka penulis tertarik untuk melakukan penelitian eksperimen dengan judul "Pengaruh Model Project Based Learning Berbantuan Penilaian Portofolio Terhadap Literasi Sains Siswa Kelas V SD Gugus IV Kecamatan Sawan".

\section{Metode}

Penelitian ini menggunakan pendekatan kuantitatif. Jenis penelitian ini adalah penelitian eksperimen, mengingat kontrol atau pengendalian variabel tidak bisa dilakukan secara ketat, atau secara penuh maka disebut dengan penelitian eksperimen semu (quasi exsperimental). Rancangan penelitian ini menggunakan desain penelitian eksperimen " non-equivalent post test only with equivalent control group design". Disajikan pada tabel 01.

\section{Tabel 01}

Rancangan eksperimen

\begin{tabular}{rcr}
\hline Kelas & Perlakuan & Post-test \\
\hline E & $X$ & $Q_{1}$ \\
$K$ & - & $Q_{2}$ \\
\hline
\end{tabular}

Keterangan:

(Dimodifikasi dari Sugiyono, 2017)

E : Kelompok Eksperimen

$\mathrm{K} \quad$ : Kelompok Kontrol

$\mathrm{X} \quad$ : Perlakuan model Project Based Learning berbantuan penilaian portofolio 


\section{- $\quad$ : Tidak mendapat perubahan \\ $Q_{1} \quad$ :Post-Test pada kelompok eksperimen (literasi Sains) \\ $\mathrm{Q}_{2} \quad$ : Post-Test pada kelompok kontrol (literasi Sains)}

Dari pola diatas terlihat bahwa kelompok pertama yang terdiri dari satu kelas merupakan kelas eksperimen (E) yang diberikan perlakuan berupa model Project Based Learning berbantuan penilaian portofolio, selanjutnya kelompok eksperimen diberikan tes akhir $\left(Q_{1}\right)$. Sedangkan kelompok kedua yang juga terdiri dari satu kelas merupakan kelas kontrol $(\mathrm{K})$ yamg tidak diberikan perlakuan atau tidak dibelajarakan dengan model Project Based Learning berbantuan penilaian portofolio, tes akhir $\left(Q_{2}\right)$ juga diberikan pada kelas kontrol. Selanjutnya kedua hasil tes akhir tes tersebut dianalisis untuk mengetahui tingkat keberhasilan perlakuan.

Populasi dalam penelitian ini adalah seluruh kelompok siswa kelas V SD Gugus IV Kecamatan Sawan Kabupaten Buleleng Tahun Pelajaran 2018/2019 berjumlah 164 siswa yang terbagi dalam delapan SD, yaitu SDN 1 Bungkulan, SDN 2 Bungkulan, SDN 3 Bungkulan, SDN 4 Bungkulan, SDN 5 Bungkulan, SDN 6 Bungkulan, SDN 7 Bungkulan, dan SDN 8 Bungkulan. Komposisi jumlah siswa tiap SD dapat disajikan pada tabel 2 berikut ini.

Tabel 02.

Komposisi Anggota Populasi

\begin{tabular}{ccccc}
\hline No & Kelas Populasi & Kelas & Jumlah \\
\hline 1 & SDN 1 Bungkulan & $\mathrm{V}$ & 20 \\
2 & SDN 2 Bungkulan & $\mathrm{V}$ & 20 \\
3 & SDN 3 Bungkulan & $\mathrm{V}$ & 34 \\
4 & SDN 4 Bungkulan & $\mathrm{V}$ & 21 \\
5 & SDN 5 Bungkulan & $\mathrm{V}$ & 24 \\
6 & SDN 6 Bungkulan & $\mathrm{V}$ & 20 \\
7 & SDN 7 Bungkulan & $\mathrm{V}$ & 8 \\
8 & SDN 8 Bungkulan & $\mathrm{V}$ & 19 \\
\hline
\end{tabular}

Jadi populasi penelitian dalam penelitian ini adalah 8 sekolah yang ada di gugus IV kecamatan sawan, kabupaten buleleng dengan jumlah siswa keseluruhan 164 orang dengan sebaran jumlah siswa setiap sekolah dapat dilihat pada tabel 2 di atas.

Pada penelitian ini teknik pemilihan sampel yang digunakan untuk memilih kelas eksperimen dan kelas kontrol adalah dengan cara Random sampling (sampling kelompok acak). Teknik ini digunakan sebagai teknik pengambilan sampel karena individu-individu pada populasi telah terdistribusi ke dalam kelas-kelas sehingga tidak memungkinkan untuk melakukan pengacakan terhadap individu-individu dalam populasi.

Tahap pertama dari delapan sekolah yang ada di Gugus III Kecamatan Banjar Kabupaten Buleleng dilakukan pengundian untuk diambil dua kelompok yang dijadikan sampel penelitian. Kedua kelompok tersebut diundi lagi untuk menentukan kelompok eksperimen yang dibelajarkan dengan model Project Based Learning berbantuan penilaian portofolio dan satu kelompok sebagai kelompok kontrol yang tidak dibelajarkan dengan model Project Based Learning berbantuan penilaian portofolio atau pembelajaran berlangsung seperti biasanya yang dilakukan oleh guru. Berdasakan hasil pengundian untuk menentukan kelompok eksperimen dan kontrol, diperoleh kelas V SD Negeri 4 Bungkulan sebagai kelompok eksperimen yang dibelajarkan dengan model Project Based Learning berbantuan penilaian portofolio dan kelas $\mathrm{V}$ SD Negeri 1 Bungkulan sebagai kelompok kontrol yang tidak dibelajarkan dengan model Project Based Learning berbantuan penilaian portofolio.

Penelitian ini melibatkan dua variabel, yaitu model Project Based Learning berbantuan penilaian portofolio sebagai variabel bebas, dan literasi Sains sebagai variabel terikat. Pada kelas eksperimen akan dibelajarkan dengan model Project Based Learning berbantuan penilaian portofolio, sedangkan pada kelas kontrol tidak dibelajarkan dengan model Project 
Based Learning berbantuan penilaian portofolio. Pembelajaran dilakukan sebanyak 7 kali pertemuan dan satu kali post test. Literasi Sains diukur melalui post test.

Dalam penelitian ini, untuk meneliti kemampuan literasi sains, digunakan tes literasi Sains yang berpedoman pada rubrik penilaian literasi Sains. Agar instrument tes yang digunakan memenuhi syarat, maka dilakukan beberapa uji yaitu uji validitas, uji reliabilitas, uji taraf kesukaran tes, uji daya beda tes.

Uji validitas instrumen dilakukan untuk mengetahui ketepatan dan kecermatan suatu alat ukur dalam melakukan fungsi ukurnya.Uji validitas pada penelitian ini yaitu yaitu uji validitas isi dan uji validitas butir item. Uji validitas isi dapat dilakukan dengan cara menyesuaikan tes dengan materi pada silabus yang ada dengan dituangkan dalam bentuk kisi-kisi. Untuk mendapatkan validasi isi dari tes literasi Sains dilakukan dengan cara membuat soal berdasarkan kisi-kisi. Selanjutnya soal tersebut dikaji oleh pakar atau uji judges yaitu oleh dosen ahli. Validitas Butir dalam penelitian ini adalah tes politomi karena berupa skor tes esai. Uji Reliabilitas dilakukan terhadap butir soal yang valid saja dengan demikian uji reliabilitas bisa dilakukan setelah uji validitas. Relibialitas tes berhubungan dengan masalah ketepatan hasil tes (Arikunto, 2016:100). Uji taraf kesukaran butir dilakukan dengan memperhitungkan banyak responden yang menjawab butir tersebut dengan benar (Candiasa: 2010). Sedangkan tingkat kesukaran perangkat tes adalah bilangan yang menunjukkan rata-rata proporsi testee yang dapat menjawab seluruh (perangkat) tes. Daya beda butir tes adalah kemampuan butir tes tersebut membedakan antara testee kelompok atas dan testee kelompok bawah. Daya beda butir merupakan pengkajian butir-butir yang dimaksudkan untuk mengetahui kesanggupan butir tes untuk membedakan peserta tes yang tergolong mampu dengan peserta tes yang tergolong tidak mampu (Candiasa, 2010: 85).

Data yang diperlukan dalam penelitian, yaitu kemampuan literasi sains.. Metode analisis data yang digunakan dalam penelitian ini adalah metode analisis statistik deskriptif dan statistik inferensial (uji-t). Analisis deskriptif digunakan untuk mengetahui deskripsi literasi Sains dengan mencari nilai mean, median, modus, standar deviasi, rentangan, dan varian. Selanjutnya, statistik inferensial digunakan untuk melakukan uji hipotesis. Sebelum uji hipotesis, dilakukan beberapa uji prasyarat berupa uji normalitas dan uji homogenitas, sedangkan metode analisis data yang digunakan untuk menguji hipotesis adalah analisis uji-t.

\section{Hasil dan Pembahasan}

Dari hasil penelitian yang telah dilakukan di SD Negeri 4 Bungkulan sebagai kelompok eksperimen dan di SD Negeri 1 Bungkulan sebagai kelompok kontrol adapun hasil analisis deskriptif data literasi Sains pada kelompok eksperimen menunjukkan bahwa skor rata-rata adalah 41, 67 dengan kategori sangat tinggi dan pengukuran literasi Sains pada kelompok kontrol menunjukkan bahwa skor rata-rata adalah 29,48 dengan kategori tinggi. Hal ini menunjukkan perbedaan antara kedua sampel. Secara lebih rinci mengenai penghitungan statistik deskriptif dari masing-masing kelompok dapat dilihat pada tabel 03.

Tabel 03

Rangkuman hasil deskripsi data literasi Sains

\begin{tabular}{lcc}
\multicolumn{1}{c}{ Statistik Deskriptif } & \multicolumn{2}{c}{ Kemampuan Siswa Dalam Literasi Sains } \\
& Kelompok Eksperimen & Kelompok Kontrol \\
\hline Mean & 41,67 & 29.48 \\
Median & 42 & 29 \\
Modus & 43 & 28 \\
Varians & 8,03 & 10,88 \\
Standar Deviasi & 2,83 & 3,30 \\
Skor Maksimum & 46 & 36 \\
Skor Minimum & 37 & 24 \\
Rentangan & 10 & 13 \\
\hline
\end{tabular}


Berdasarkan hasil analisis despriptif pada Tabel 3, skor rata-rata literasi Sains kelompok eksperimen lebih besar dibandingkan skor rata-rata kelompok kontrol. Tinjauan ini didasarkan pada rata-rata skor dan kecendrungan skor literasi Sains siswa yang diperoleh kedua kelompok.

Pada kelompok eksperimen, rata-rata skor literasi Sains pada kelompok eksperimen adalah 41,67 berada pada kategori sangat tinggi dan sebagain besar skor siswa cenderung berada di atas rata-rata. Gambaran data literasi Sains pada kelompok eksperimen dapat disajikan pada Gambar 01.

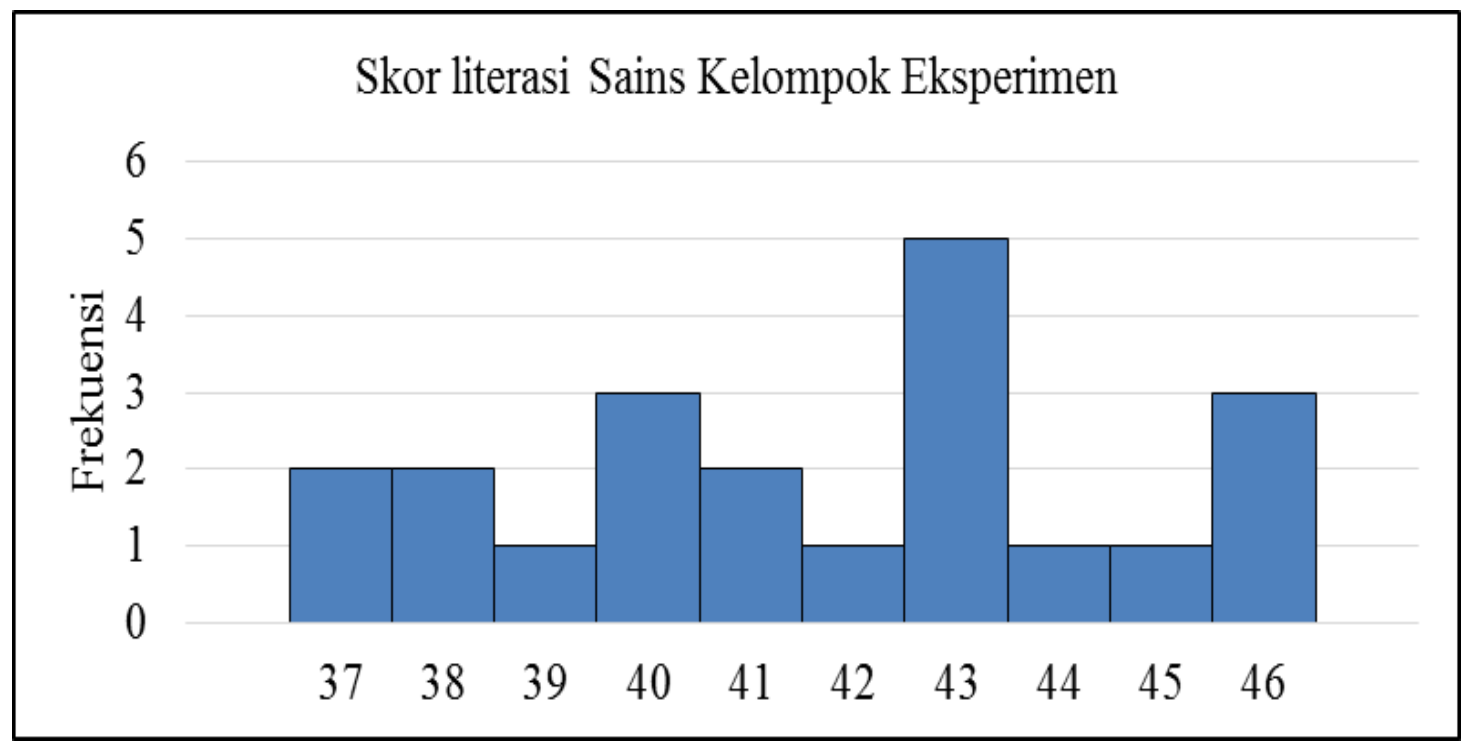

\section{Gambar 01}

Histogram Data literasi Sains Kelompok Eksperimen

Pada kelompok kontrol, rata-rata skor literasi Sains pada kelompok kontrol adalah 29,48 berada pada kategori tinggi dan sebagain besar skor siswa cenderung rendah. Gambaran data literasi Sains pada kelompok kontrol dapat disajikan pada Gambar 02.

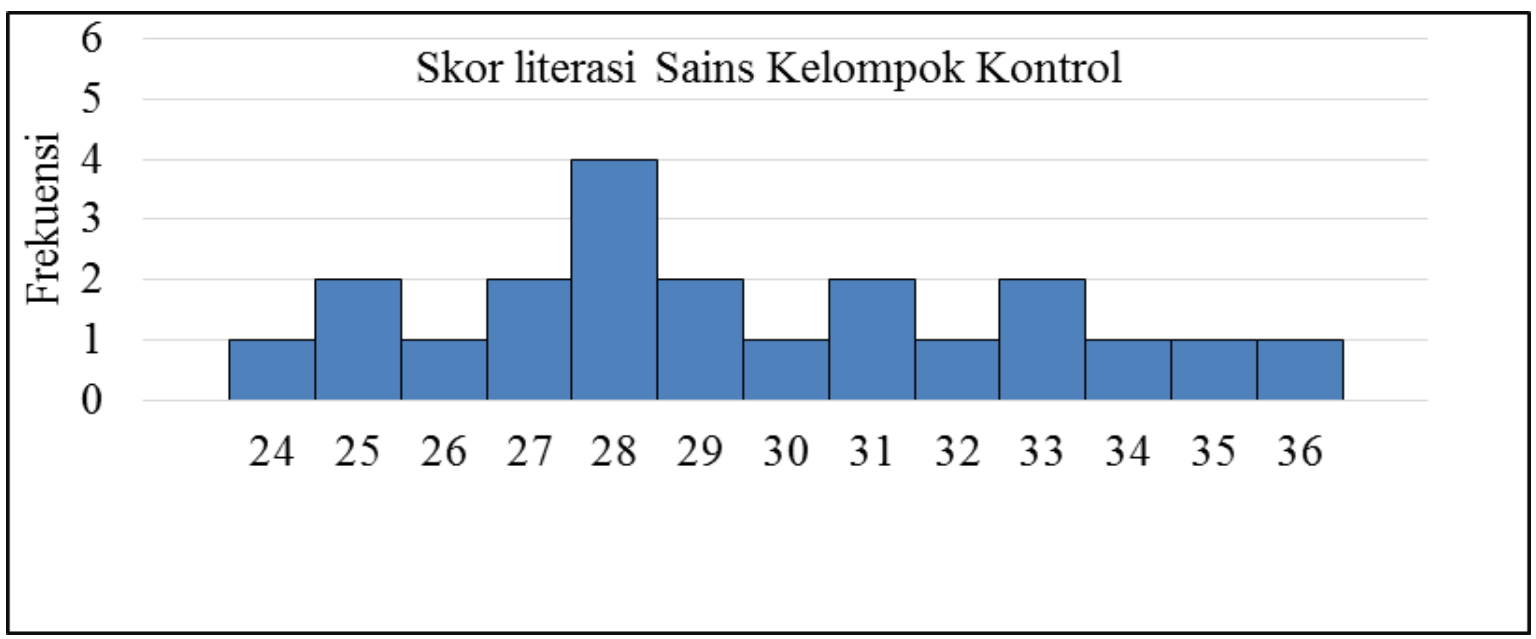

Gambar 02.

Histogram Data Literasi Sains Kelompok Kontrol 
Berdasarkan paparan tersebut, literasi Sains pada kelompok eksperimen lebih baik daripada literasi Sains pada kelompok kontrol. Hasil uji prasayat analisis menunjukkan analisis uji normalitas didapatkan $t_{\text {hitung }}<t_{\text {tabel }}(2,78<11,070)$ maka dapat disimpulkan bahwa data berdistribusi normal. Analisis uji homogenitas didapatkan bahwa $F_{\text {hitung }}<F_{\text {tabel }}(1,35<4,08)$ maka dapat disimpulkan bahwa kedua kelompok data homogen.

Berdasarkan hasil uji hipotesis yang telah dilakukan, adapun hasil yang diperoleh setelah melakukan uji-t adalah $t_{\text {hitung }}=12.84$. Kemudian ditentukan harga $t_{\text {tabel }}$ dengan cara yang telah ditentukan $(\mathrm{db}=21+21-2=40)$, sehingga diperoleh hasil $t_{\text {tabel }}=2,021$. Berdasarkan harga $t_{\text {hitung }}$ dan $t_{\text {tabel }}$ diketahui bahwa $t_{\text {hitung }}>t_{\text {tabel }}(12,84>2,021)$, sehingga $H_{0}$ ditolak dan $\mathrm{H}_{1}$ diterima. Hal ini menunjukkan bahwa terdapat perbedaan yang signifikan literasi Sains antara kelompok siswa yang dibelajarkan model pembelajaran project based learning berbantuan penilaian portofolio dan kelompok siswa yang tidak dibelajarkan model pembelajaran project based learning berbantuan penilaian portofolio pada siswa kelas V semester II di SD Gugus IV Kecamatan Sawan.

Berdasarkan deskripsi data hasil penelitian, diperoleh data bahwa terdapat perbedaan literasi Sains antara kelompok siswa yang dibelajarkan model pembelajaran Project Based Learning berbantuan penilaian portofolio dan kelompok siswa yang tidak dibelajarkan model pembelajaran Project Based Learning berbantuan penilaian portofolio. Hal ini berdasarkan pada rata-rata skor literasi Sains siswa dan hasil yang diperoleh setelah melakukan ujit.padakelompok siswa yang dibelajarkan model Project Based Learning berbantuan penilaian portofolio memperoleh skor literasi Sains lebih tinggi dibandingkan kelompok siswa yang tidak dibelajarkan dengan model Project Based Learning berbantuan penilaian portofolio.

Dengan adanya perbedaan kemampuan literasi Sains dari kedua kelompok, menandakan bahwa model Project Based Learning berbantuan penilaian portofolio berpengaruh terhadap literasi Sains siswa. Hal ini disebabkan oleh penerapan model Project Based Learning yang mampu melibatkan siswa untuk berpartisipasi aktif dalam kegiatan proyek untuk meningkatkan aspek siswa dalam mengidentifikasi isu-isu (masalah) ilmiah, menjelaskan fenomena ilmiah, dan menggunakan bukti-bukti ilmiah sehingga dapat membentuk kemampuan literasi Sains.

Model Project Based Learning merupakan model belajar yang menggunakan masalah sebagai langkah awal dalam pengumpulan pengetahuan baru berdasarkan pengalamannya dalam beraktivitas secara nyata (Wulandari, 2018).Dalam penelitian, model Project Based Learning diintegrasikan dengan penilaian portofolio untuk dapat meningkatkan literasi Sains siswa.

Penerapan model Project Based Learning adalah: sintak pertama, mengajukan pertanyaan mendasar atau esensial, sebelum diberikannya tugas berupa proyek, guru memberikan permasalahan atau isu kepada siswa agar terbiasa mengenali permasalahan ilmiah yang terjadi dalam Sains. Guru dan siswa akan melakukan tanya jawab terkait isu yang diberikan sampai pada akhirnya siswa dapat mengidentifikasikan isu yang diberikan tersebut. Berdasarkan hal tersebut, secara tidak langsung siswa akan belajar mengidentifikasi isu-isu (masalah) ilmiah yng terdapat pada aspek kompetensi literasi Sains.

Sintak kedua, mendesain perencanaan proyek: pada tahap ini siswa sudah mengetahui identifikasi masalah yang dianalisis, kemudian siswa mencari solusi dari permasalahan tersebut melalui sebuah proyek. Siswa merencanakan proyek apa yang harus dilaksanakan, apa saja alat dan bahan yang diperlukan untuk membantu penyelesaian proyek, apakah proyek yang akan dilaksanakan bersifat individu atau berkelompok, dimana proyek itu akan dilaksanakan.

Sintak ketiga, menyusun jadwal: dalam hal ini guru dan siswa menyusun jadwal dalam penyelesaian proyek. Jadwal ini disusun untuk mengetahui berapa lama waktu yang dibutuhkan dalam pengerjaan proyek.Jadwal yang sudah tersusun wajib disepakati oleh seluruh anggota kelas.Pada sintak kedua dan ketiga, secara tidak langsung dapat melatih siswa dalam menjelaskan fenomena ilmiah yang merupakan kompetensi kedua dari literasi Sains.Dalam hal ini disebut melatih menjelaskan fenomena ilmiah karena siswa sudah mampu mengambil tindakan dan menerapkan proyek dari permasalahan yang sedang dibahas. 
Sintak keempat, memonitoring peserta didik dan kemajuan projek: pada tahap ini guru berperan vital untuk memonitoring perkembangan siswa dalam pelaksanaan proyek. Apabila siswa menemukan permasalahan, maka guru menjadi fasilitator dan membimbing temuan siswa. Dalam kegiatan ini, guru memperhatikan kinerja dari masing-masing siswa agar guru tidak salah dalam memberikan penilaian kepada siswa.

Sintak kelima, menguji hasil: dalam hal ini, guru memberikan penilaian terhadap proyek yang telah dilaksanakan. Sebelum adanya penilaian, siswa wajib mempresentasikan hasil proyeknya di hadapan teman-teman, jika ada siswa yang melakukan presentasi maka siswa yang lain menyimaknya. Proyek yang dihasilkan siswa bukan hanya berupa produk, tetapi juga ternasuk hasil penelitian, LKS, dan lain sebagainya. Ketika siswa telah selesai melakukan presentasi, guru akan memberikan penilaian dengan menggunakan format penilaian portofolio dan akan memberikan komentar-komentar sesuai dengan hasil dari proyek siswa. Dalam hal ini guru tidak perlu merasa terbebani dalam memberi penilaian, karena guru sudah dapat melihat proses yang dilalui siswa yang terlihat pada sintak ke empat.

Sintak keenam, mengevaluasi pengalaman: setelah guru memberikan penilaian kepada siswa, guru dan siswa menyimpulkan dan mengevaluasi proyek yang telah dilksanakan. Proses ini dilakukan secara individu maupun kelompok. Pada tahap ini siswa diminta untuk mengungkapkan perasaan dan pengalamannya selama menyelesaikan proyek. Secara tidak langsung dari penerapan sintak ke empat, lima, dan enam dapat meningkatkan aspek literasi Sains dalam hal menggunakan bukti-bukti ilmiah.

Penerapan model Project Based Learningmemberikan keuntungan bagi siswa karena dapat meningkatkan motivasi belajar siswa. Laporan-laporan tertulis tentang proyek itu banyak yang mengatakan bahwa siswa suka tekun sampai kelewat batas waktu berusaha keras dalam mencapai proyek (Titu, 2015). Maka dari itu, ada manfaat yang dirasakan oleh siswa setelah menerapkan model Project Based Learningberbantuan penilaian portofolio antara lain: mampu meningkatkan motivasi belajar siswa, keterampilan pemecahan masalah siswa menjadi semakin meningkat, terjadi kerjasama dan kolaborasi yang baik antar siswa, secara tidak langsung dapat meningkatkan kemampuan berkomunikasi siswa, melatih siswa dalam mengorganisasikan sebuah proyek, meningkatkan keterampilan siswa dalam mengatur waktu dengan sebaik-baiknya.

Selain model Project Based Learning, dampak positif yang dirasakan siswa secara khusus dalam pelaksanaan penilain portofolio sangat baik. Penggunaan portofolio ada banyak hal bagi pembelajaran meliputi: portofolio memberikan kesempatan bagi siswa untuk mengatur pembelajaran mereka sendiri; portofolio dapat digunakan untuk menentukan tingkat prestasi; portofolio memungkinkan siswa menyajikan suatu pandangan holistik dari prestasi akademik yang tertinggi, keterampilan, dan kompetensi; portofolio dapat digunakan untuk menentukan tingkat perkembangan siswa; portofolio dapat digunakan untuk memahami bagaimana siswa berpikir, beralasan, mengorganisasi, menyelidiki, dan komunikasi (Al-Tabany, dkk, 2015: 291).

Berdasarkan teori di atas, adapun dampak yang dirasakan setelah penerapan penilaian portofolio tersebut adalah siswa sangat termotivasi untuk mengikuti proyek, langkah-langkah dalam model Project Based Learning dilaksanakan dengan baik dari awal perencanaan sampai pada tahap evaluasi dengan tujuan agar skor yang diperoleh siswa tidak mengecewakan. Ketika siswa diberikan proyek, siswa akan mengerjakan dengan tekun sesuai dengan prosedur yang ditetapkan, setelah proyek selesai, maka guru akan menilai proyek dengan lembar kemajuan peserta didik yang ada pada penilaian portofolio. Guru membagikan lembar kemajuan peserta didik kepada masing-masing siswa agar siswa dapat melihat hasil kinerja yang telah mereka lakukan. Dalam lembar kemajuan peserta didik berisi skor siswa, komentar guru, catatan, kelebihan maupun kelemahan dari proyek yang dibuat, penilaian tersebut sangat terbuka, sehingga siswa dapat mengetahui skor yang didapatkan secara langsung.Ketika siswa mendapatkan nilai dan komentar bagus, siswa sangat senang dan terus berupaya untuk mempertahankan skor yang didapatkan atau bahkan meningkatkan skor yang diberikan pada saat itu. Kemudian jika ada siswa yang memiliki skor masih rendah, maka guru akan memberikan kesempatan kepada siswa untuk belajar lebih giat dan membangkitkan semangat siswa agar proyek selanjutnya mendapatkan skor yang lebih tingi dibandingkan hari itu. Hasil 
proyek siswa disimpan ke dalam kantong khusus bersama dengan format kemajuan peserta didik dengan tujuan agar siswa dapat melihat peningkatan hasil belajarnya yang disimpan dalam sebuah dokumen.

Sedangkan pada kelas kontrol tidak menerapkan model Project Based Learning berbantuan penilaian portofolio, siswa pada kelas kontrol melakukan pembelajaran seperti biasa (berpusat pada guru) dengan menggunakan metode ceramah, penugasan, sesuai dengan versi yang diberikan oleh guru kelasnya. Guru hanya mentransfer pengetahuan yang ada di buku siswa, bahkan selama penyelenggaraan penelitian guru sangat jarang menggunakan media, dan inovasi-inovasi pembelajaran. Setiap pembelajaran IPA guru melakukan hal yang sama yaitu diawali dengan membaca buku siswa selama beberapa menit, setelah itu guru akan menanyakan apa isi materi yang telah dibaca, kemudian dilanjutkan dengan Tanya jawab antar guru dan siswa. Ketika siswa sudah paham, maka guru akan melanjutkan dengan menugaskan siswa untuk menjawab pertanyaan-pertanyaan yang ada pada buku siswa. Jika gaya mengajar tersebut terus diterapkan maka pengetahuan Sains, isuisu Sains yang ada di masyarakat sedikit diketahui, yang menyebabkan literasi Sains siswa akan tetap berada pada kategori rendah seperti yang disampaikan oleh Organisasi Internasional yaitu OECD dalam penyelenggaraan PISA.

Hasil temuan pada penelitian ini sesuai dengan penelitian yang dilakukan oleh Desi Novita Anggun Sari pada tahun 2017 dalam jurnal Universitas Negeri Semarang yang berjudul "Pengaruh Pembelajaran Berbasis Proyek terhadap Kemampuan Literasi Sains Siswa". Hasil penelitian menunjukkan bahwa profil kemampuan literasi Sains siswa menunjukkan bahwa pembelajaran berbasis proyek dengan bantuan model lebih baik pengaruhnya terhadap literasi Sains siswa dibandingkan pembelajaran ceramah. Dari penelitian tersebut memiliki persamaan variabel bebas dan variabel terikat untuk meningkatkan literasi Sains siswa.Muhammad Fahri Mundzir dalam Jurnal Pena IImiah tahun 2017 dengan judul "Project Based Learning untuk Meningkatkan Kemampuan Literasi Sains Siswa SD". Hasil penelitian, penggunaan model pembelajaran PBL dapat meningkatkan literasi Sains siswa sekolah dasar pada materi peristiwa alam secara signifikan baik di kelompok tinggi, kelompok sedang, dan kelompok rendah.

Dengan demikian dapat disimpulkan bahwa penerapan model Project Based Learning berbantuan penilaian portofolio berpengaruh positif terhadap literasi sains kelompok eksperimen yaitu siswa kelas V SD Negeri 4 Bungkulan, Kecamatan Sawan, Kabupaten Buleleng.Dalam pemaparan temuan hasil penelitian di atas, dapat diketahui bahwa model Project Based Learning berbantuan penilaian portofolio berpengaruh terhadap literasi Sains siswa kelas V SD gugus IV Kecamatan Sawan.

Pernyataan tersebut juga diperkuat dengan keterangan guru kelas yang menyatakan bahwa pengaruh dari model Project Based Learning berbantuan penilaian portofolio sangat baik diterapkan di SD, melalui model tersebut siswa sangat senang dalam pembelajaran, siswa menjadi lebih aktif dan antusias mengikuti pembelajaran. Karena sejatinya siswa SD senang dengan kegiatan konkrit yang dapat meyakinkan dirinya bahwa mereka bisa dan mampu mengerjakan sesuatu dengan sendiri.

\section{Simpulan dan Saran}

Berdasarkan hasil pengujian hipotesis dan pembahasan, maka dapat disimpulkan bahwa terdapat pengaruh yang signifikan model Project Based Learning berbantuan penilaian portofolio terhadap literasi Sains siswa kelas V SD Gugus IV Kecamatan Sawan, Kabupaten Buleleng.

Adapun saran yang dapat disampaikan berdasarkan hasil penelitian yang dilakukan adalah sebagai berikut: (1) Disarankan kepada siswa agar lebih kreatif dalam menyelesaikan masalah yang diberikan dalam pembelajaran, selain itu siswa agar mampu mengatur waktu dalam pembelajaran agar dapat mengikuti proses pembelajaran dengan maksimal. (2) Disarankan kepada guru di sekolah dasar agar dapat menggunakan model-model yang inovatif agar peserta didik lebih antusias menerima pembelajaran. Selain itu guru dapat menggunakan 
media pembelajaran yang mndukung agar dapat meningkatkan literasi sains siswa. Serta tidak lupa guru selalu mengaitkan pembelajaran dengan situasi-situasi atau permasalahan Sains dalam kehidupan sehari-hari. (3) Disarankan kepada Kepala Sekolah hendaknya mampu mengambil tindakan dalam upaya meningkatkan kualitas pembelajaran dan kualitas mutu pendidikan melalui pengarahan kepada guru-guru sebagai alternatif pilihan menggunakan model pembelajaran inovatif dalam setiap pembelajaran. (4) Disarankan kepada peneliti yang mengadakan penelitian lebih lanjut tentang model pembelajaran Project Based Learning dalam bidang Sains atau yang lain agar dapat menjadi acuan kepustakaan serta memperhatikan kendala-kendala yang di alami dalam penelitian ini sebagai bahan pertimbangan untuk perbaikan dan penyempurnaan penelitian yang akan dilaksanakan.

\section{Daftar Pustaka}

Aqil, D. A. 2017. "Literasi Sains Sebagai Konsep Pembelajaran Buku Ajar Biologi di Sekolah". Jurnal Pemikiran, Penelitian Pendidikan dan Sains.Vol.5, No.2.

Arikunto, S. 2016. Dasar-dasar Evaluasi Pendidikan. Jakarta: Bumi Aksara.

Astutik, S. 2019. "Pengaruh Model Colaborative Creativity (CC) Terhadap Kemampuan Literasi Sains dan Hasil Belajar Fisika Siswa di SMA". Saintifika.Vol.21, No.21.

Candiasa. 2011. Pengujian Instrumen Penelitian Disertai Aplikasi ITEMAN dan BIGSTEPS. Singaraja: Undiksha Press.

Dharsana, K. 2014. "Upaya Peningkatan Aktivitas dan Hasil Belajar, Dengan Model Pembelajaran Kooperatif Dengan Berbantuan Penilaian Portofolio Melalui Lesson Study Bermuatan Nilai Kearifan Lokal dan Enterpreneurship Pada Mata Kuliah Pengembangan Pribadi Konselor di Jurusan BK FIP Undiksha". Seminar Nasional Riset Inovatif.

Fatmala, S., A., 2017."Pembelajaran Kontekstual Untuk Meningkatkan Literasi Sains Siswa SD Kelas V Pada Materi Peristiwa Alam”. Jurnal Pena IImiah. Vol. 2, No.1.

Fitariya, F. 2018. "Meningkatkan Literasi Sains di SDN Sidokumpul Dengan Metode Experimen". Jurnal PGSD Universitas Muhamadyah Sidoarjo.

Mulyadi, Eko. 2015. "Penerapan Model Project Based Learning Untuk Meningkatkan Kinerja dan Prestasi Belajar Fisika Siswa SMK". Jurnal Pendidikan Teknologi dan Kejuruan. Volume 22, Nomor 4.

OECD. 2016. Programme for International Student Assesment (PISA) Result From PISA 2015. Paris: OECD.

Redhana, I.W. 2019. "Mengembangkan Keterampilan Abad Ke-21 Dalam Pembelajaran Kimia".Jurnal Inovasi Pendidikan Kimia. Vol.13, No.1.

Shofiyah, N.2015. "Deskripsi Literasi Sains Awal Mahasiswa Pendidikan IPA Pada Konsep IPA". Journal Pedagogia.Vol.4, No.2.

Sugiyono. 2017. Metode Penelitian Pendidikan (Pendekatan Kuantitatif, Kualitatif dan $R \& D$ ). Bandung: Alfabeta.

Wulandari, Y. 2018. "Penerapan Model Project Based Learning Untuk Meningkatkan Hasil Belajar Siswa di Kelas V MIN 38 Aceh Besar". Prosiding Seminar Nasional Biotik. 